\title{
The Czech (Czechoslovak) 'Osmichki' in the Novels by Milan Kundera: The Problem of Memory and Forgetting
}

\author{
Albert Valiakhmetov \\ Guzel Golikova \\ Nadezhda Pomortseva \\ Kazan (Volga Region) Federal University, Russian Federation \\ Email: albert80@mail.ru, guzel-golikova@yandex.ru, nadpom@rambler.ru
}

Doi:10.5901/mjss.2015.v6n2s1p543

\begin{abstract}
The article examines the notion of Czech (Czechoslovak) 'osmichki' in the novels of a famous writer Milan Kundera. The Czech (Czechoslovak) history (inclusive of 'osmichki' of 1968) is shown in the author's literary work not only as a historical and political but an ethical category. It is connected with the problem of national identity and forms the inner world of the characters in Kundera's novels and that of the author himself (the interpenetration of the character's life story and real history). The author views the world and man in this world through the realm of existential and post-modern philosophy trying to understand the drama of a nation along with a man's daily drama in history. The 'past-present-future' triad is interpreted by the writer though the Past as the starting and the turning point. In this view the motif of memory and forgetting gains a particular impact in the early works by Kundera. The choice between memory and forgetting determines the evaluation of both fictional and real historical character as well as the author's view. It provides a peculiar interpretation of history, man in history, national and personal identity through the history of daily routine.
\end{abstract}

Keywords: Czech (Czechoslovak) 'osmichki'; the motif of memory and forgetting; existentialism and post-modernism.

\section{Introduction}

Milan Kundera, a famous Czech writer in exile (born in 1929, Brno, Czechoslovakia) is worldly recognized. In 1948 he joined the Communist Party of Czechoslovakia, but in 1950 he was expelled from it. In the 'thaw years' the promising writer was reinstated in the Communist Party, however, in 1970 was expelled again for taking part in 'The Prague Spring of 1968' (Shchepanovich, 2005). Consequently, Kundera was deprived not only of political but of civil privileges of a resident, too: in 1969 he was dismissed and all his publications were outcast of the formal booklist 'printed in Czechoslovakia'. He was deprived of the 'privilege to work', his plays would not be staged (Grenier, 2006). In 1974 he received a job invitation from the University of Rennes in France, however, for a year he was not allowed to leave the country. In 1975 Kundera and his wife Vera Grabankova were given a permission to leave for France (Carlisle, 1985). Four years later after The Book of Laughter and Forgetting had been published, The Czechoslovakia government deprived him of the citizenship (Shchepanovich, 2005).

Even this short glimpse of Milan Kundera's biography seems sufficient enough to understand the importance of recent political and social history of Czech Republic in Milan Kundera's genesis as a writer. The issue brought the authors of the article to formulating the following objectives of the research. They are to determine the peculiarities of artistic realization of 'the osmichki' phenomenon in the literary work by Milan Kundera, to reveal the issue of memory and forgetting in post-modern texts while considering the artistic manner of the writer and his axiological orientations.

\section{The Czech 'Osmichki' as a Phenomenon of Czech History and Literature}

\subsection{Historical background of the Czech 'osmichki'}

The historical events: the Soviet occupation of Czechoslovakia in 1968, political pursuit, expel from the Communist Party had a great impact on the artistic manner of the writer, the choice of themes and problems considered in his literary work. Other Czechoslovakia exile writers of 'the first wave', who left the county in the late 1960s - early 1970s (J. Škvorecký, P. 
Kogout, A. Lustig, Ya. Benesh, Z.Salivarová, S.Richterová, L. Moniková, Ya. Veyevoda) share his peculiar lucid approach to the problems of the recent Czech history in their works. Social and political events, witnessed by the 'older generation' Czech immigrant prosaic authors (World War II, the Crisis of 1948 and 1968) became a part of their individual life story. The Democratic Velvet Revolution of 1989, formally putting an end to Kundera's life in exile, heralded the beginning of a no less important period and was critically worked through by the writer in 1990 s.

A particular interest for the immigrant writers seems to be the topic of 'man in history'. An individual, the making of his/her character, his/her fate is perceived by these authors as historically and socially determined notions and processes. One of the most vivid examples is The Joke, a pre-exile novel by Milan Kundera, where the whole life of the main character fails due to an unlucky witty comment, taken by his insightful contemporaries for a harmful ideological detriment (Boyarskaya, 2010).

The creative work by Kundera also reflects the historical events in Czech (Czechoslovakia) - hereinafter Czech history; consequently, it determines the theme of this paper which generally aims at revealing the peculiarities of the artistic perception of 'osmichka' notion in Czech history in Kundera's prose.

To develop the main idea of the paper it is worth specifying the term 'osmichki' itself. By 'osmichki' the Czech historians mean the events crucial for the Czech Republic (Czechoslovakia) that took place in the years ending with 'eight'. The root of the word 'osmichki' is osm, which is number eight in the Czech language, whereas 'osmichki' (osmički) could be rendered as 'numbers eight'. A few most important 'osmichki' in Czech history in the 20th century are: 1918 - the establishment of the Czechoslovak Republic after the dissolution of the Imperial Austria; the Munich Agreement of 1938, followed by the Nazi army occupation of Czechoslovakia; the 1948 Soviet Take-over in the new democratic Czechoslovakia Republic; the Soviet occupation reacting to 'the Prague Spring of 1968', followed by a twenty-year-long 'normalisation' period. The next take-over happens not in 1988 but in 1989. Taken reversed the final figures make up '68' - back to freedom (or 'reversed osmichka' as regarded in Czech Republic itself).

The memory of these events remained not only in the mind of those who witnessed them, but gained a peculiar interpretation in the literary works by Milan Kundera. Meanwhile 'the osmichki', namely the years of 1948, 1968, played an essential, sometimes existential role in the writer 's life and determined a few of the remarkable characteristics of his works:

Autobiographism: Kundera's works can be considered as his artistic biography or 'chronicle narrative' or even 'a generation of Czech intelligentsia life-story';

Essayism: Kundera not just writes, he reflects. Sometimes in his novels the border between fiction and a philosophic treatise seems particularly vague. For example, in the Immortality (1990) reflection prevails over the plot so much that the work could be regarded as a mix of a novel and an essay (Shchepanovich, 2005).

\subsection{The Czech 'osmichki' in Milan Kundera's literary work}

Milan Kundera demonstrates a peculiar relationship with history; he perceives it from metaphysical and existential as well as post-modern point of view. He works in the new epoch, when a radical inversion of the scientific picture of the world takes place: microlevels and micriprocesses, centrifugal trends, localization, fragmentation and individualization have been put forward. The world has broken to a thousand pieces and the post-modernists take it for granted (Philosophia istorii, 1999).

Referring to the Czech 'osmichki' and the crucial year of 1968, Kundera comprehends it as a European philosopher, brought up into the tradition of Renaissance and Enlightenment (Diderot, Goethe), on the one hand, and of the newest philosophic ideas of the $20^{\text {th }}$ century (mostly, Martin Heidegger), on the other. At the same time history is seen by Kundera through a prism of post-modern paradigm, the characteristic features of which are clearly revealed on the artistic-esthetic level of his works. They are dilution of strict binary oppositions, rejection of the traditional 'self', erasure of personality, emphasis on a multisided 'self', multilevel composition of the text, polysemantic ideas and points of view, intertextuality, rhizome and others (Kireeva, 2004, p.113).

The writer goes beyond the ordinary criticism of the socialistic realia, he gives insights into the human problems beyond a particular historical event. The crisis of the society is revealed in the characters. The way Kundera sees the fates of his fiction characters and the real history of the country is biased by the motif of "absurdity of being"; thus, the writer is inevitably drawn to irony (Sherlaimova, 2002, p. 114). One can speak of the 'Kafka' motif in the author's literary work where the absurdity of being interpreted as a twist of fate is revealed in different phantasmagorical forms and images (Carlisle, 1985). A particular author's perception of history and man's life story in history determines the erotic motif in his novels as one of the forms of expressing the inner protest against socialistic formality (The Unbearable Lightness of Being (1984) as well as a means of revealing the post-modern idea of the writer in a man's daily routine. 
In Ignorance (2000) Kundera summarizes the notion of 'osmichki' in the Czech (Czechoslovakia) history and the way he understands it:

\begin{abstract}
"Like blows from an ax, important dates cut deep gashes into Europe's twentieth century. ... The history of the Czechs in the twentieth century is graced with a remarkable mathematical beauty owing to the triple repetition of the number twenty. In 1918, after several centuries, they achieved their independence, and in 1938 they lost it. In 1948 the Communist revolution, imported from Moscow, inaugurated the country's second twenty-year span; that one ended in 1968 when, enraged by the country's insolent self-emancipation, the Russians invaded with half a million soldiers. The occupier took over in full force in the autumn of 1969 and then, to everyone's surprise, took off in autumn 1989-quietly, politely, as did all the Communist regimes in Europe at that time: and that was the third twenty-year span. Our century is the only one in which historic dates have taken such a voracious grip on every single person's life" (Kundera, 2000, p. 89).
\end{abstract}

The Czech 'osmichka' of 1968 being a crucial year marked by the start-up of post-modernism as a mass intellect movement in many ways models life and inner world of the characters in the early works of the writer. The author's "self" determines the historical and political issues raised in the novels in their traditional context as a criticism of the current political system (Grenier, 2006). But in the episodes building the composition of his novels a post-modern concept of history is revealed. Here the author's concern is not social structure and processes but rather people's daily routine and conditions of living (Sidortsov, 2006).

Milan Kundera is inspired by a problem of a person's daily routine which he sets on the particular historical background. For him the phenomenon of human being is influenced by Heidegger's philosophy: human being is understood within the context of his/her real every day relationship with the world (Sidortsov, 2006). The development of this strategy in the author's novels is particularly important - sometimes fiction allows to see into deep hidden forces, that appear much more precise in the variation of history rather than in the one that had itself realised (Boyarskaya, 2010). Simultaneously, the problem of an object's self-identification is revealed (be it an individual or a nation). So, in comparison with 'the second wave' Czech immigration writers Kundera's literary work, though written in languages other than Czech, remains deeply authentic, Czech by nature, marked with the feeling of 'a mission' of the literature in 'exile' according to the tradition of the past centuries (Kundera, 1999). He is focused on the problem of national identity, and while formulating it the writer logically makes insights into the history of his native land.

\title{
3. The Czech 'Osmichki' and the Problem of Memory and Forgetting in Milan Kundera's Novels
}

The above-mentioned principles of constructing the fiction world of his texts, where the 'osmichka' of 1968 acts as a starting point, explain the peculiar methods of solving a historical and philosophic problem applied by Milan Kundera. This includes both the questions of man and his self-identity bringing us to the problem of memory and forgetting, which is viewed in Kundera's works as an ethical rather than historical or political problem.

The author first raised it in 1960s. In his report on culture and politics made at the Fourth Convention of the Czechoslovakia Writers' Union Kundera remarked, that the Czech culture, being isolated for a long time first by the Nazi occupation, later by Stalinism, is prone to losing its historical memory (Shchepanovich, 2005).

The idea dates back to the writer's early novel The Joke (1967), which brought him European popularity. Reflecting on the consequences of one of 'the osmichki' - the Munich Agreement of 1938 (when the heads of the four countries: Great Britain, France, Germany and Italy almost authorised the annexing by Germany a part of Czechoslovakia, the Sudetenland) and the occupation of Czechoslovakia that followed it in 1939, Kundera says: "They tried to make us believe we had no right to exist, we were nothing but Czech-speaking Germans"(Kundera, 1992, p. 55). However, the return to their history was a kind of struggle for existence, for their future:

\begin{abstract}
"We needed to prove to ourselveswe'd existed before and still did exist. We all made a pilgrimage to the sources. The war gave us new impetus. In the last year of the Nazi occupation, the Ride of the Kings was staged in our village. There was an army camp in the town, and German officers jostled the local population in the streets. The Ride turned into a demonstration. A host of colorful young men on horseback, with sabers. An invincible Czech horde. A deputation from the depths of history. That's how all the Czechs saw it, and their eyes lit up" (Kundera, 1992, p. 56).
\end{abstract}

It is quite remarkable that the writer keeps referring to the Czech national and cultural realia, traditions and landmarks, inclusive of the lives of outstanding representatives of Czech literature and art. Kundera is sure that the folk song or folk rite is a tunnel beneath history, a tunnel that preserves much of what wars, revolutions, civilization have long since destroyed aboveground. It is a tunnel through which I see far into the past (Kundera, 1992, p. 58). 


\section{1 'The past-present-future' triad}

The problem of memory is closely connected with 'the past-present-future' triad. Generally, it means that our present determines what we are to remember from our past; the latter, in its turn, determines our future. In this regard, Milan Kundera's novel The Book of Laughter and Forgettting (1978) is quite remarkable; it is made up of a series of stories and essays, united by the main characters (Tamina and Kundera himself), themes and images (laughter, angels, Prague). As with some other Kundera's works, this one is inspired by a musical composition. The plot of the novel is incomplete, separate episodes serve as variations of the main theme: the characters struggle with forgetting and come to the idea that the past cannot be called upon to help the present, the past cannot be improved.

The process of self-identification, the attempt of an individual to cast his/her role and acquire some new properties, which began in the second half of the $20^{\text {th }}$ century, is quite discernible in Kundera's prose (Brodsky, 2013). In 'the pastpresent-future' triad it is the Past that plays the main role, first of all in the process of self-identification of both a person and a nation. No wonder, the word combination 'the flavor of the past' has an undoubtedly positive connotation (Kundera, 1998). It makes a sort of frame that holds man in this world:

"She wants to have her notebooks so that the flimsy framework of events, as she has constructed them in her school notebook, will be provided with walls and become a house she can live in. Because if the tottering structure of her memories collapses like a clumsily pitched tent, all that Tamina will be left with is the present, that invisible point, that nothingness moving slowly toward death"( Kundera, 1999, p. 119).

The relationships of the characters and their past as well as the memor) become an essential characteristic that determines the author's attitude to his hero/heroine and prompts a similar attitude on the part of the reader. Inability 'to remember' means the weakness of the character, the unsteadiness and hopelessness of their position:

"He [Yakub] tried to get firmly in mind the idea that he was leaving his country. He tried hard to evoke his past life. He tried hard to see it as a landscape he looked back on with longing, a landscape vertiginously distant. But he could not manage it. What he did succeed in seeing behind him in his mind's eye was tiny, compressed like a closed accordion. He had to make an effort to evoke the scraps of memory that could give him the illusion of a destiny that had been lived" (Kundera, 1998, p. 64)

Yakub pays for his past with his present. A similar character can be found in other works by Milan Kundera. The author cannot limit himself with life for today only:

"She [Ruzhena] was passing the Slavia, the worst restaurant in the spa town, a filthy cafe where the locals came to drink beer and spit on the floor. In the old days it had probably been the best, and from those times there still remained a small garden with three red wooden tables and their chairs (paint peeling), a memento of bourgeois pleasure in openair brass bands and dancing and parasols propped against the chairs. But what did she know about those times, this young woman who merely went through life on the narrow footbridge of the present, devoid of all historical memory" (Kundera, 1998, p. 72).

Kundera emphasises that a desire to leave something after themselves is typical for almost all humans:

"The irresistible proliferation of graphomania among politicians, taxi drivers, hildbearers, lovers, murderers, thieves, prostitutes, officials, doctors, and patients shows me that everyone without exception bears a potential writer within him, so that the entire human species has good reason to go down into the streets and shout: "We are all writers!" For everyone is pained by the thought of disappearing, unheard and unseen, into an indifferent universe, and because of that everyone wants, while there is still time, to turn himself into a universe of words. One morning (and it will be soon), when everyone wakes up as a writer, the age of universal deafness and incomprehension will have arrived" (Kundera, 1999, p. 147).

Comparing 'the past' and 'the present', Kundera is still not in favour of the former:

"They [people] shout that they want to shape a better future, but it's not true. The future is only an indifferent void no one cares about, but the past is filled with life, and its countenance is irritating, repellent, wounding, to the point that we want to destroy or repaint it. We want to be masters of the future only for the power to change the past. We fight for access to the labs where we can retouch photos and rewrite biographies and history" (Kundera, 1999, p. 30-31).

All the characters in the book struggle with forgetting: Tamina struggles with forgetting and keeps remembering her 
late husband who died long ago; Mirek tries to forget his love for a beautiful girl. The motif of memory and forgetting gains a historical and political context when the writer raises an issue of historical and social amnesia. He makes an important conclusion that the struggle of man and power is the struggle of memory and forgetting (Kundera, 1999).

Meanwhile, the prospect of the struggle of man and forgetting appears quite doubtful as:

"Today history is no more than a thin thread of the remembered stretching over an ocean of the forgotten, but time moves on, and an epoch of millennia will come which the inextensible memory of the individual will be unable to encompass; whole centuries and millennia will therefore fall away, centuries of paintings and music, centuries of discoveries, of battles, of books, and this will be dire, because man will lose the notion of his self, and his history, unfathomable, unencompassable, will shrivel into a few schematic signs destitute of all sense. Thousands of deaf-anddumb Rides of Kings will set out with their piteous and incomprehensible messages, and no one will have the time to hear them out" (Kundera, 1992, p.122).

\section{2 'Memory correction'}

Eventually, Kundera comes to admission of the inevitable 'victory of forgetting':

"Most people deceive themselves with a pair of faiths: they believe in eternal memory (of people, things, deeds, nations) and in redressibility (of deeds, mistakes, sins, wrongs). Both are false faiths. In reality the opposite is true: everything will be forgotten and nothing will be redressed. The task of obtaining redress (by vengeance or by forgiveness) will be taken over by forgetting. No one will redress the wrongs that have been done, but all wrongs will be forgotten" (Kundera, 1992, p.123).

The same idea is revised in the later novel Ignorance, published in France in 2000:

"And once he was abroad, did his memory lose its noxious influence? Yes; because there Josef had neither reason nor occasion to concern himself with recollections bound to the country he no longer lived in; such is the law of masochistic memory: as segments of their lives melt into oblivion, men slough off whatever they dislike, and feel lighter, freer" (Kundera, 2000, p. 78).

A considerable part of Kundera's reflection is made upon a problem that might be called 'a memory policy', that is revealing the strategy of the state (the system) 'to interfere in the memory'. When 'interference in the memory' is made at the state level, it can be called 'rewriting history':

"He [Mirek] had erased her, her and his love for her, he had scratched out her image until he had made it disappear as the party propaganda section had made Clementis disappear from the balcony where Gottwald had given his historic speech..." (Kundera, 1999, p. 30).

The strategy of 'memory correction' was widely applied in the $20^{\text {th }}$ century; however, it dates back to as far as the 1620s:

"When the Jesuits, after the defeat of the Czech Reformation in 1621, tried to reeducate the people in the true Catholic faith, they swamped Prague with the splendor of Baroque cathedrals. The thousands of petrified saints gazing at you from all sides and threatening you, spying on you, hypnotizing you, are the frenzied occupation army that invaded Bohemia three hundred fitty years ago to tear the people's faith and language out of its soul.... Wandering the streets that do not know their names are the ghosts of monuments torn down. Torn down by the Czech Reformation, torn down by the Austrian Counter-Reformation, torn down by the Czechoslovak Republic, torn down by the Communists; even the statues of Stalin have been torn down. In place of (hose destroyed monuments, statues of Lenin are nowadays springing up in Bohemia by the thousands, springing up like weeds among ruins, like melancholy flowers of forgetting" (Kundera, 1999, p.216).

The strategy of 'memory correction' in Czechoslovakia was widely applied by new authorities. Here Milan Kundera refers to the image of Klement Gottwald:

"In February 1948, the Communist leader Klement Gottwald stepped out on the balcony of a Baroque palace in Prague to harangue hundreds of thousands of citizens massed in Old Town Square. That was a great turning point in the history of Bohemia. A fateful moment of the kind that occurs only once or twice a millennium. Gottwald was flanked by his comrades, with Clementis standing close to him. It was snowing and cold, and Gottwald was bareheaded. Bursting with solicitude, Clementis took off his fur hat and set it on Gottwald's head.... Four years later, Clementis was charged 
with treason and hanged. The propaganda section immediately made him vanish from history and, of course, from all photographs. Ever since, Gottwald has been alone on" (Kundera, 1999, p. 3-4).

So it is quite understandable that in Kundera's prose 'recollection' is not merely psychological but a meaningful moral and even political act:

"It is 1971, and Mirek says: The struggle of man against power is the struggle of memory against forgetting. With this he is trying to justify what his friends call carelessness: meticulously keeping a diary, preserving his correspondence, compiling the minutes of all the meetings where they discuss the situation and ponder what to do. He says to them: We're not doing anything that violates the constitution. To hide and feel guilty would be the beginning of defeat" (Kundera, 1999, p. 4).

Making insights into the problem Kundera introduces a notion of 'the president of forgetting' - the idea refers to Gustav Husak:

"If Franz Kafka is the prophet of a world without memory, Gustav Husak is its builder. After T. G. Masaryk, who was called the Liberator President (every last one of his monuments has been destroyed), after Benes, Gottwald, Zapotocky, Novotny, and Svoboda, he is the seventh president of my country, and he is called the President of Forgetting.... Husak drove one hundred forty-five Czech historians from the universities and research institutes. If they want to liquidate a people they start with taking away its memory. Gradually they destroy its books, its culture, its history and the language that might sooner or later become a mere folklore and die" (Kundera, 1999, p. 217-218).

As a result, Milan Kundera comes to a very important conclusion on the role of history in the life of an individual and the society:

"History is a series of ephemeral changes, while eternal values are immutable, perpetuated outside history, and have no need of memory..." (Kundera, 1999, p. 256).

These words are echoed in his other utterance on the earlier history of the country:

"It is not a coincidence that during the period of the so-called 'normalization' the sadder people were, the more and the louder speakers played. They were inviting the occupied country to forget the bitterness of history and indulge itself in enjoying life" (Kundera, 1999, p. 248).

\section{Research Methodology}

While carrying out the research presented in the article the authors applied a number of research instruments. They were general scientific methods, namely analysis, synthesis, induction, deduction as well as special ones. The latter included the biography study instrument, which allowed to analyze the literary work by Milan Kundera referring to his biography. Evidently, Kundera's literary work reflects his individual life story. Thus an insight into his biography gave the researchers a clue to deeper understanding of his novels. The discourse-analysis method applied in the research helped to determine and structuralize in Kundera's works such concepts as 'memory', 'forgetting', 'past'. The context-analysis method allowed the understanding how the crucial Czech 'osmichki' are embodied, discussed and interpreted in the novels of the worldfamous 'exile' writer. The same method provided for the interpretation of Kundera's novels in the prism of the postmodern paradigm.

\section{Concluding Remarks and Discussion}

In conclusion, we can summarize that the works by Milan Kundera give one of the best answers to the philosophical question that could be given through literature: why should one study and learn one's history? The question is closely connected with the idea of self-identification of both a person and a nation one belongs to. History becomes a starting point in solving the question of national identity and the role of man in history in general. The idea of Kundera lies in the fact that people should remember history, otherwise, they lose orientation and the reality loses its sense (Sherlaimova, 2002, p. 168).

Milan Kundera, overwhelmed with the political essence of being, reflects upon the fractional dissolution of being via the notion of "evil laughter" (thus putting forward the motif of laughter and joke). The writer goes beyond the particularlynational and specifically-historical to the eternal concept of life. Here a peculiar focus is made on the category of the Past, 
as opposed to the Present-Nothing and the Future-Nothing. The category of the Past, viewed though the paradigm of the historical events, gains the properties of an ethical one. It determines the consciousness of the characters and, consequently, their life. Kundera's heroes and heroines have to make a choice - memory or forgetting. The ability to remember gives an individual his/her personal identity, leads him/her beyond the impersonal existence and destroys the idea of the Present-Nothing.

The deep philosophical and historical understanding of the existential role 'the osmichki' played in the construction of the artistic world in the writer's literary work appears closely connected with the problem of national and personal identity of his fictional and real-life characters. This makes the author refer to the national codes, create a peculiar system of images of his characters, united in a multi-faced 'self' and, consequently, a particular composition of the novel based on a synthesis of the novel and the essay, the existential and the post-modern one.

\section{References}

Boyarskaya, A. A., (2010), Proza cheshskoy emigratsii 1980-1990h godov. Avtor. Geroy. Povestvovatel. [Czech Immigrant Prose of 1980-90s. Author. Character. Narrator.]. [Online] Available: http://cheloveknauka.com/proza-cheshskoy-emigratsii-1980-1990-hgodov-avtor-geroy-povestvovatel (January 10, 2015).

Brodsky, A. I., (2013), Obretenie identichnosti [Gaining Identity]. [Online] Available: http://philosophy.spbu.ru/userfiles/rusphil/25-5.pdf (January 09, 2015).

Carlisle, O. (1985). A Talk with Milan Kundera. The New York Times, 1985, May 19, 72, 1.

Grenier, Y. (2006). Milan Kundera on Politics and the Novel. History of Intellectual Culture, 2006, 6(1), 1-18.

Heidegger, (2014). [Online] Available: //http://hpsy.ru/authors/x104.htm (January 11, 2015).

Kireeva, N. V. (2004). Postmodernism v zarubezhnoy literature [Postmodernism in Western Literature] - Moscow: Flinta: Nauka.

Kundera, M., (2000), Ignorance. [Online] Available: http://www. static.ow.ly/docs/\%20lgnorance / PDF (January 05, 2015).

Kundera, M., (1998), The Farewell Waltz - New York: Harper Collins. [Online] Available: http://www. static.ow.ly/docs/ The \%20Farwell\%20Waltz/ PDF (January 13, 2014).

Kundera, M., (1992), The Joke. - New York: HarperCollins. [Online] Available: http: // file:///C:/Users/user/AppData/Local/Temp/Rar\$ EX00.438/The\%20Joke.htm (January 13, 2015).

Kundera, M., (1999), The Book of Laughter and Forgetting - New York: HarperCollins. [Online] Available: http:// www.static.ow.ly/docs/ The\%20Book\%20of\%20Laughter\%20and\%20Forgetting/ PDF (January 08, 2015).

Philosophia istorii. Postmodernistskaya paradigma istorii [Philosopy of History. Postmodern Paradigm of History], (1999). Moscow: Gardiriki.

Shchepanovich, M., (2005), Milan Kundera. Biographia [Milan Kundera. Biography]. [Online] Available: http://www.intlclub.narod.ru/l Club/Literature/Kundera.html (January 11, 2015).

Sherlaimova, S. A. (2002). Literatura 'Prazhskoy vesni': do i posle [The Literature of Prague Spring: Before and After]. Moscow: Institut Slavyanovedeniya RAN.

Sidortsov, V. N. (2006). Metodologicheskiye problemy istorii [Methdological Problems of History]. Moscow: Tetrasystems. 